INTERNATIONAL JOURNAL OF RESEARCHES IN BIOSCIENCES, AGRICULTURE AND TECHNOLOGY (C) VISHWASHANTI MULTIPURPOSE SOCIETY (Global Peace Multipurpose Society) R. No. MH-659/13(N) www.vmsindia.org

\title{
SPIDER DIVERSITY OF RUNDIV, SIDHESHWAR AND RAMNADI AREA OF CHANDOLI NATIONAL PARK
}

\author{
S. B. More \\ P.V.P. Mahavidyalay Kavathe Mahankal, Tal Kavathe Mahankal Dist Sangli State Maharashtra Country india \\ spiderfauna@rediffmail.com
}

\begin{abstract}
:
Spider diversity studied from Northern Western Ghats of Chandoli National Park. Western Ghats area of India is considered as an important biodiversity hot spot. A total of 58 species belonging to 38 genera and 16 families are recorded from the study area during 2012-2014. The Sanctuary area has got Global National significance. The spiders from Family araneidae, lycosidae, salticidae and thomisidae are the characteristic families of this region. Keywords: Spider, Western Ghats, Chandoli
\end{abstract}

\section{Introduction:}

Chandoli National Park is spread over the geographical area of 32 illages located at the junction of Sangli, Satara, Kolhapur and Ratnagiri districts, The area of this Sanctuary is 308.97 sq. $\mathrm{km}$. Warna river originates in protected area near village Patherpung. The Sanctuary area has got Global National significance. The rich biodiversity of this area provides nice opportunity for research and education. The present study of Spider fauna will be a great significance from the point of view biodiversity. As such there is no work on any aspect of Spider fauna of Chandoli National Park hence with the present work I will try to fill up a gap of information regarding biodiversity of Spider fauna in these areas. Spiders comprise one of the largest orders of animals. The pioneering contribution on the taxonomy of Indian spiders is that of European arachnologist Stoliczka (1869). Review of available literature reveals that the earliest contribution by Blackwall (1867); Karsch (1873); Simon (1887); Thorell (1895) and Pocock (1900) were the pioneer workers of Indian spiders. They described many species from India. Tikader (1980, 1982), Tikader, and Malhotra (1980a,b) described spiders from India. Tikader (1980) compiled a book on Thomisidae spiders of India, comprising two subfamilies, 25 genera and 115 species. Pocock (1900) and Tikader (1980, 1987) made major contributions to the Indian Arachnology. Tikader (1987) published the first list of Indian spiders, which included 1067 species belonging to 249 genera in 43 families. Gajbe (1995-2003) described 147 new spider species from different habitats of India. The updated spider checklist given by Keswani et al. (2012) of SGB Amravati University Arachnology laboratory shows 1686 species from 438 genera and 60 families. According to world spider catalogue there are Spiders of protected areas in
India, are studied by Gajbe (1995a) in lndravati Tiger Reserve and recorded 13 species. Rane and Singh (1977) recorded five species and Gajbe (1995b) 14 species from Kanha Tiger Reserve, Madhya Pradesh. Gajbe (2003) prepared a checklist of 186 species of spiders in 69 genera under 24 families distributed in Madhya Pradesh and Chhattisgarh. Patel (2003) described 91 species belonging to 53 genera from Parabikulum Wildlife Sanctuary, Kerala. ManjuSilwal et al. (2003) recorded 116 species from 66 genera and 25 families of spiders from Puma wildlife Sanctuary, Dangs, Gujarat. Sivaperuman et al., (2004) studied the spiders in Desert National Park, Rajasthan. So far nobody has worked out or studied the spider fauna from this region of Chandoli National Park and hence we have decided to explore the spider diversity from this area.

\section{Material and Methods:}

The study were made during early morning hours (6 hours to 9 hours) and day time (16 hours to 18 hours), from different parts of the microhabitats, like, rolled or folded leaves, plant branches, leaf litter, tree trunks, rock surface, grass blades dry hay and grasses, moist places, under stones, pebbles, humus, bushes, on the bark and branches of trees, water logged locations, etc. The Lycosids and Gnaphosids were studied from the soil surface and also from the river beds. Most of the spiders searched visually. Each spider was identified mainly on the basis of morphological characteristics, epigyne and or palp structure by using the literature (Kaston, 1978; Barrion and Litsinger, 1995; Tikader, 1987 and Mujumdar, 2007). The details of body parts of specimens were examined under a good quality stereo zoom microscope. The identification of species was carried out by the comparison of morphological features with the help of published literature, 
standard books and field guides.

\section{Result and Discussion:}

A total of 58 species (Table-1) belonging to 38 genera and 16 families were recorded from the study area during 2011-2013. Among all these 16 families, high diversity was observed in the families Araneidae (15 species) > Salticidae(11 species) > Lycosidae (09 species) > Thomisidae 05 species). Table : 1 Diversity of spiders in Rundiv Sidheshwar and Ramnadi region of Chandoli National Park 1. Araneidae Orb Web Spiders 1. Araneus mitifica (simon) Female 2. Araneus himalayaensis (Tikadar) 1975 3. Argiope aemula (Walckenaer) Female 4. Argiope aemula (Thorell) Male 5. Argiope anasuja Female 6. Cyclosa bifida (Doleschall) Female 7. Cyclosa hexatuberculata (Tikadar) Female 8. Cyclosa confraga (Thorell) 18929. Cyclosa insulans (Costa), 1934. 10. Gasteracantha geminata (Fabricius) 1798, Female 11. Gasteracantha kuhli(C L. Koch) Female 12. Telecantha brevispina (,Doleschall) Female 13. Larinia emertoni (Gajbe and gajbe) 2004 14. Neoscona mukerjei (Tikader) Female 15. Neoscona bengalensis (Tikadar and Bal,) 1981 2. Corinnidae - Ant Mimicking Sac Spiders 16. Castianeira zetes (Simon) 1897 Female 3. Eresidae - Social Spiders 17. Stegodyphus sarasinorum (Karsch,) 1891 Female 4. Gnaphosidae - Ground Spiders/Mouse Spiders 18. Gnaphosa poonaensis (Tikadar) 19735. Hersiliidae - Two Tailed Spiders/Bark Spiders 19 Hersilia Savignyi (Lucas) 1836 Female 6. Lycosidae - Wolf Spiders 20 Archtosa indica (Tikadar and Malhotra) 198021 Evippa mandlaensis (Gajbe)2004 22 Hippasa greenalliae (Blackwell) 1867. 23 Hippasa hansae(Gajbe and Gajbe) 199924 Hippasa holmerae (Thorell) 189525 Hippasa madhuae(Tikadar and Malhotra)1980 26 Pardosa birmanica (Simon) 188427 Pardosa leucopalpis (Gravely)1924 28 Pardosa ranjani Gajbe 2004 7. Oxyopidae - Lynx Spiders 29 Oxyopes pankaj(Gajbe and Gajbe) 200130 Oxyopes tikaderi (Biswas and Majumdar) 1995 31 Peucetia viridian (Stoliczka)1869. 8. Philodromidae - $\quad$ Running Crab Spiders/Elongated Crab Spiders 32 Philodromus pali (Gajbe) 2000 9. Pholcidae Daddy Long Leg Spiders 33 Pholcus phalangioides (Fuesslin)1775 10. Pisauridae Nursery Web Spiders 34 Pisaura gitae Tikadar 1970 Female 35 Nilus marginatus Simon 1888 11. Salticidae - Jumping Spiders 36 Epeus albus (Proszynski)1992 $37 \quad$ Menemerus bivittatus (Dufour)1831 38 Hyllus semicupreus
(Simon)1885 39 Myrmarachne jajpurensis (Proszynski) 199240 Myrmarachne (Maratha Tikadar) $1973 \quad 41$ Myrmarachne satarensis (Narayan) 191542 Myrmarachne uniseriata (Narayan) $1915 \quad 43$ Phintella vittata C. L.(Koch)1846 44 Plexippus petersi Female 45 Rhene decorate (Tikadar) 197746 Telamonia dimidiata (simon 1899) Female 12. Scytodidae Spitting Spiders 47 Scytodes fusca, (Walckenaer) 1837 13. Sparassidae - Giant Crab Spiders 48 Heteropoda venatoria,(Linnaeus,) 176749 Olios millet (Pocock,) 190114. Tetragnathidae 50 Leucauge decorate (Blackwall), 1864 Female 51 Tetragnatha javanus,(Thorell,) 1890. 15. Theridiidae - Comb Footed Spiders/Cob Web Spiders 52 Latrodectus hasselti (Thorell) $1870 \quad 53$ Rhomphaea projiciens (O. P. Cambridge). 1896 16. Thomisidae - Crab Spiders/Flower Spiders 54 Thomisus pathaki (Gajbe) 200455 Thomisus pooneus (Tikadar) $196556 \quad$ Xysticus bharatae(Gajbe and Gajbe)1999 57 Xysticus breviceps (O. P. Cambridge)1885 58 Xysticus tikaderi (Bhandari and Gajbe) 2001

\section{Conclusion:}

Thus the results indicate the dominance of araneidae, lycosidae, salticidae and thomisidae. A total of 58 species (Table-1) belonging to 38 genera and 16 families were recorded from the study area during 2011-2013. The rich biodiversity of this area provides nice opportunity for research and education. Spiders have a very significant role to play in ecology by being exclusively predatory and thereby maintaining ecological equilibrium.

\section{Acknowledgement:}

Author thanks UGC, New Delhi for their financial support.

\section{Reference:}

[1] Barrion, A.T and Litsinger, J. A. (1995): Riceland spiders of south and Southeast Asia, CAB International, Cambridge, UK : 1-700.

[2] Biswas, B. and Biswas, K. (2004): Araneae : Spiders. In: Fauna of Manipur, State Fauna Series 10, Zoological Survey of India: 25-46.

[3] Blackwell, J. (1867): Description of seven new species of East Indian spiders recieved from the Rev. O P. Cambridge. Annals and Magazine of Natural History. (3)14: 36-45.

[4] Churchill, T. B. 1997. Spiders as ecological indicators: An overview for Australia. Memoirs of the Museum of Victoria. 56 (2): 331-337. 
[5] Churchill, T.B. and Ludwig, J.A. 2004. Changes in Spider Assemblages along Grassland and Savanna Grazing Gradients in Northern Australia. Rangel. J. 26(1): 3-16.

[6] Gajbe,P. (2003): Checklists of Spiders (Arachnid; Araneae) of Madhya Pradesh and Chattisgarh. Zoos.Print Journal 18 (10): 12231226.

[7] Gajbe,U. A. (1995a): Spiders Fauna of Conservation Areas: Fauna of Kanha Tiger Reserve, Madhya Pradesh. Z000logical Survey of India, Publication: 27-30.

[8] Gajbe, U. A. (1995b): Spiders, Fauna of Conservation Areas: Fauna of Indravati Tiger Reserve, Madhya Pradesh. Zoological Survey of India, Publication: 53-56.

[9] Gajbe, U. A. (1999): Studies on some spiders of the family Oxyopidae (Araneae : Arachnida) from India: Records of Zoological Survey of India 97(3): 31-79.

[10] Gajbe, U. A.(1987): A new scopodes spiders from India Araneae: Gnaphosidae). Bulletin of Zoological Survey of India. 8: 285-287.

[11] Gadgil, M. 1992. Biodiversity: Time for hold steps. Ibid. PP. 21-23.

[12] Karsch, E. (1873): Verzeichniss Westfalischer Spinnen (Araneiden) Verh.naturh. Ver. Preuss.Rhein.Westfal.10: 113-160.

[13] Kaston, B. J. (1978): How to know spiders? The pictured key Nature series. Wm. C. Brown. Co. Publishers. Dubuque, Iowa, USA: 1272.

[14] Keswani,S. Hadole, P. andRajoria, A. (2012): Checklist of spiders (Arachnida: Araneae) From India 2012. Ind. j. Arachnol.Voil(1); 1-129.

[15] Majumder, S.C. (2007) : Pictorial handbook on spiders of of Sunderbans : West Bengal.Zoological Survey of India :138pp.

[16] Manju Silwal; B. Suresh and Bonny Pilo. (2003): Spiders of Puma wildlife Sanctuary, Dangs, Gujarat. Zoos. Print Journal 18 (11): $1259-1263$.

[17] McIver, J. D., Moldenke, A. R. and Parson, G.L. 1990. Litter spiders as bioindicators of recovery after clear-cutting in a western coniferous forest. Northwest Environmental Journal. 6 : 410-412.
[18] Patel, B. H. (2002): Fauna of Protected Areas -I, Spiders of Vansda National Park, Gujarat. Zoos. Print Journal 18 (4): 1079 -1083.

[19] Patel, B. H. (2003): Fauna of Protected Areas - A Preliminary list of Spiders with the descriptions of three new species from Parambikulum Wildlife sanctuary, Kerala. Zoos. Print Journal 18 (10): 1207 -1212.

[20] Patel, B. H. and Vyas, R. V. (2001): Spiders of Hingolgadh Nature Sanctuary, Gujarat, India. Zoos Print Journal. 16(9): 589590.

[21] Platnick, N. I. (2013): The world spider catalog, version 13.5. American Museum of History, onlineat http://research.amnh.org/iz/spiders/catalog.

[22] Rane, P. D and Singh, R. K.(1977): Spiders (Arachnida: Araneae) from Kanha National Park, Madhya Pradesh, India. Newsletter Zoological Survey of India., 3(2): 84.

[23] Scarff, N and Coddington, J.A.1997. A Phylogenetic analysis of the orb- weaving spider family Araneidae (Arachnida,Araneae)120:355434.

[24] Sherriffa, W.R. 1919. A contribution to the study of south Indian arachnology. Annals and Magazine of Natural History 4 (9): 220-253

[25] Sebastian P. A. and Peter K. V. 2009. Spiders of India

[26] Stoliczka, F. (1869): Contribution towards the Knowledge of Indian Arachnoidae. Journal of Asiatic Society of Bengal. 38: 201-251.

[27] Thorell, T. (1895): Descriptive Catalogue of the spiders of Burma. Brit. Mus. Lond. UK: 1406

[28] Tikader, B. K and Malhotra, M.S. (1980): The fauna of India. Spiders (Thomisidae and Lycosidae). Zoological Survey of India, Calcutta: 44pp.

[29] Tikader, B. K. (1980): Fauna of India Araneae: Spiders, Vol. I (Araneidae \& Gnaphosidae). Zoological Survey of India.448 pp.

[30] Tikader, B. K. (1982): Fauna of India Araneae: Spiders, Vol. II (Thomisidae and Lycosidae). Zoological Survey of India.533 pp.

[31] Tikader, B. K. (1987): Hand book of Indian Spiders. Zoological Survey of India: $251 \mathrm{pp}$. 